\title{
HOW ARE THEY TELLING THE STORY? REFLECTIONS ON VARIATIONS ON A THEME AN EDITORIAL
}

Ernst M Conradie

Department of Religion and Theology University of the Western Cape

\begin{abstract}
This editorial serves as an introduction to the essays on the theme of "How are they telling the story?" included in this volume. It unpacks the multiple layers of the narrative that is at stake in this theme.
\end{abstract}

Key Words: Conversation partners, Economic trinity, Narrative theology

The contributions included in volumes 97 and 98 of Scriptura are derived from a colloquium on the theme of "How are they telling the story?" that was held at the University of the Western Cape from 24 to 26 October 2007. This theme calls for some further clarification - as the colloquium itself amply illustrated.

In the (open) invitation to colleagues to participate in the colloquium the purpose of the colloquium was explained in the following way: "To hear from a variety of South African systematic theologians how their long-standing/primary conversation partner(s) would narrate the story of God's work, that is, the story of God's work in creation, (evolutionary) history, sin, providence, redemption, church and mission and the completion of God's work. It is assumed that theologians have been telling this story in different ways and that it may be illuminating to juxtapose the different versions of the story - as understood by their South African conversation partners."

As expected, this theme was problematised in the various contributions and during the discussion at the colloquium itself. In fact, every word in the formulation calls for some further reflection:

\section{'they'}

Participants in the colloquium each had to indicate which of their conversation partners' work they would focus on. This was indicated in the programme as such. As a result it was fairly clear to whom the 'they' referred in this case, namely to Oepke Noordmans (18711956), Karl Barth (1886-1968), Edmund Schlink (1903-1984), Karl Rahner (1904-1984), Arnold van Ruler (1908-1970), Ben Marais (1909-1999), Jürgen Moltmann (1926-), Johann-Baptist Metz (1928-), Robert Jenson (1930-), Sallie McFague (1933-), Rosemary Radford Ruether (1936-). Elizabeth Johnson (1941-), Wentzel van Huyssteen (1942-) and Grace Jantzen (1948-2006).

However, this selection of conversation partners begs several further questions and observations.

- Firstly, these names obviously reflect the conversation partners of those South African theologians who received and accepted the invitation and who could eventually come. Several people withdrew from the programme due to other commitments, including 
Anthony Balcomb (on Kwame Bediako), John de Gruchy (on Dietrich Bonhoeffer), Steve de Gruchy (on Reinhold Niebuhr), Nico Koopman (on Harry Kuitert), Clint le Bruyns (on Paul Tillich) and Robert Vosloo (on John Calvin). Annalet van Schalkwyk (on Sallie McFague) had to withdraw at the last minute due to ill health, although she and Tony Balcomb submitted their contributions afterwards.

- Secondly, it should be noted that each of the participants has other conversation partners whom they may have selected as well. The selection of conversation partners is therefore arbitrary in two senses of the word, namely in terms of the selection of speakers and the selection of their conversation partners.

- Thirdly, it was from the beginning quite striking that South African theologians do tend to have long-distance conversation partners from very different geographical backgrounds. Only Danie Veldsman worked on a fellow South African theologian while Hans Engdahl (from Sweden, now working at UWC) also selected a (long-distance) South African conversation partner, namely Ben Marais. If such a colloquium were to be held in other countries (for example Germany) most of the conversation partners would probably have come from that country. The colloquium therefore had something distinctly South African about it, reflecting its colonial history since the other conversation partners listed on the programme came from the Netherlands (2), Germany (4), Switzerland (1), England (1) and the USA (4).

- Fourthly, it was notable that there were four women included as conversation partners. This would probably have been quite different if the colloquium was held 10 years ago. It should also be noted that male participants selected men as conversation partners while female conversation partners selected women. The way in which the programme was organised, namely on the basis of the birth years of the conversation partners implied that all the women spoke towards the end of the colloquium. This was remarkable in the sense that one almost (but as I will note below not quite) had the feeling that the programme rehearsed the history of South African theologies, starting with a Dutch Reformed theologian (Noordmans) and concluding with a lesbian British Quaker (Jantzen). In terms of confessional backgrounds the programme reflected a similar variety, namely with six Reformed, two Lutheran, one Methodist, one Quaker and four Roman Catholic conversation partners.

- Fifthly, it was painfully obvious that no black theologian and no African theologian were selected as conversation partners. Moreover, the participants at the colloquium were all classified as 'white' in the previous regime although a number of other UWC students also attended the sessions. It should be noted that Nico Koopman and Clint le Bruyns originally agreed to participate but had to withdraw due to other commitments. They would have spoken on Harry Kuitert and Paul Tillich respectively. Only Anthony Balcomb (who also had to withdraw) would have spoken (upon my request) on an African theologian, namely Kwame Bediako. It should also be noted that the invitations were widely distributed to all the major theological institutions in the country more than a year before the colloquium was held.

How should this skewed representation be assessed? My own conclusion is that this reveals something about the state of South African theology. There are still rather few persons of colour occupying senior positions at theological institutions in South Africa. The younger black South African theologians probably could not muster the courage to prepare a paper on what was generally agreed to be an enormously difficult theme - since one had to capture the life work of a theologian who - in most cases - have produced literally hundreds of publiccations. To study such a theologian's work in some depth (to have a long-standing conver- 
sation partner) requires extended opportunities for studying theology, usually after the completion of a doctoral thesis - that many have not had, for several reasons.

Another observation may be added here, namely that African theology is still a relatively young discourse. There are some but not yet many African theologians who have produced a corpus of writings that could be studied in the same way as, say, in the case of Karl Barth or Karl Rahner. Only a few African theologians have made substantial contributions on the traditional loci of systematic theology. Secondary literature, not only drawing from but also analysing and assessing the work of African theologians by other African theologians, is still quite scarce. Something similar applies to South African theologians who are not Euro-Africans. While there were many exponents of black theology and liberation theology in South Africa in the 1970s and the 1980s, few of them have sustained their research outputs in the field of Christian theology in the 1990s and beyond. Several persons have accepted senior positions in government or in university management. One would certainly hope, if a similar colloquium were to be held in 10 year's time, that there would emerge theologians who could reflect critically on the work of, let us say, Alan Boesak, Russel Botman, Simon Maimela or Desmond Tutu.

Finally, it is important to add that reconstructing the work of another theologian is, of course, very subjective and deeply personal. Several participants commented on why they have come to select this particular conversation partner and how they have been deeply influenced by her or him. In most cases this did not allow for much critical distance. As a result, it was not all that clear who 'they' are who are telling the story. In each case one has to say that it is one's conversation partner's version of the story as reconstructed for better or for worse by oneself.

\section{'the story'}

Which story are 'they' telling? What is meant by 'the' story? Despite the instructions in the original invitation that the story here refers to "the story of God's work", and probably because of the ambiguity embedded in that, it was abundantly evident that there was 'rich confusion' as to which story was at stake here. I suggest that one can identify multiple layers of this story. In each case there are various versions of that story as told by the participants, their conversation partners and the conversation partners of the conversation partners.

- Firstly, one may mention the personal life story of one's conversation partner. In many if not all cases the particular social context shaped the person's life and work decisively. It was therefore necessary to tell the life story of one's conversation partner. However, in that case there emerges a further ambiguity. Who is telling that story? In many cases this life story may be derived from autobiographical comments in an author's work. However, in all cases it was obviously the participant in the colloquium offering a reconstruction of that life story, or, more precisely, offering brief excerpts from that life story. In terms of the contributions included in this volume of Scriptura it is especially Naude on Schlink and Trisk on Jantzen that highlighted the significance of this layer of the story.

- Secondly, there is the story of a person's theological oeuvre. Many participants recognised the need to offer an account of developments in the work of their conversation partner. This is the always interesting task of identifying such developments in someone else's work, the way in which their insights flourished, how new themes were explored and "how someone's mind has changed" (or has not changed). This stimulates, for example reflections on the differences between the 'early Barth' and the 'later Barth'. Again, if this 
is the story that is told, it is not quite clear who is telling the story. Who are 'they' in this case? In terms of the contributions included here, it is especially Naude on Schlink, Rakoczy on Johnson and Veldsman on Van Huyssteen who focused on this layer of the story.

Others simply offered an all too brief introduction to the work of an author, trying to capture something of their background, life, fields of interest, writings, views and influence. This genre is well-known in compendiums on twentieth century theologians and their theologies (e.g. The modern theologians edited by David Ford). See for example Theron on Noordmans, Lombard on Van Ruler and Ackermann on Ruether.

- Thirdly, there are cases where a large corpus of secondary material on a theologian's life and work has developed. In twentieth century Christian theology this is for example the case with Barth and Bonhoeffer. Such secondary research may well create its own history, where dramatic new insights may emerge long after a person's death and where there may develop fierce conflicts over how a theologian's legacy may best be understood. It would for example be quite possible to tell the (hi)story of Luther research. This is most clearly evident in Smit's reflections on Barthian scholarship although it would still be difficult to reconstruct a history of such scholarship.

- Fourthly, in reconstructing someone else's story, one is unavoidably also telling one's own story. Often textbooks on South African history say more about the time in which they were written than about the times which they are writing about. The same applies to books about the historical Jesus. This is all the more evident in the case where one has found a long-term conversation partner. To spend years of one's life studying another person's work becomes a very personal and intimate matter. It is often not easy to distinguish between one's own position and that of one's conversation partner, or to maintain some critical distance. For an acknowledgement of such deep influences and indeed friendships, see for example Shutte on Rahner, Rakoczy on Johnson and Veldsman on Van Huyssteen.

The story that is told could also refer to the themes about which a conversation partner has written. The question is then no longer "How can I tell their story?" but "Which story are they telling?" This was the intended focus of the colloquium, albeit that the previous four layers of the story could clearly not be avoided in the process. The problem, though, is that it is not at all clear which story is told in each case and whether this is indeed a story and, even if it is, whether the story is 'told' in narrative form - or whether it would be more appropriate to speak of 'reflections' on that story. Are they 'telling' the story or are they thinking about the story? Or is it perhaps the case that we are not telling the story, but that we are part of the narrative told by a divine Storyteller.

Which story are they telling? Or should one say with Jenson: Whose story are they telling? Here it is again possible to identify multiple layers (added here to the four layers mentioned above):

- One may focus on a sequence of historical events associated with the lives of (in some cases legendary) figures such as Abraham, Isaac and Jacob, or Sarah, Rebecca and Rachel, and their descendants - including Moses, David, Solomon, the prophets of Israel, Jesus of Nazareth and Paul. It should be noted that this sequence of events may be narrated in the form of a story but that these events are not by themselves a story. The events also necessarily transcend the story about such events. The event cannot be fully captured by the story. This is for example evident from the many versions of the life of Jesus of Nazareth as told in the early church already, not to mention more recent historical Jesus research. The point here is that any story on these events would select 
only some incidents, place them in a particular sequence with added interpretative comments. Moreover, as David Tracy has argued, this distinction between event and text (story) can scarcely be underestimated. Despite the high claims made by the Christian tradition about the authority of the biblical texts, the texts have to seen as (merely) witnesses to an event that is more important than the witnesses themselves. In Tracy's formulation: We believe in Jesus Christ, (in continuity) with the apostles (not in the apostles). ${ }^{1}$

- In my inaugural lecture (which formed part of the colloquium) I suggested that these events (which I described somewhat inaccurately as 'a story') are embedded in a larger history which may be narrated in the form of multiple other stories. I used the image of a palimpsest to suggest that these 'stories' are written across one another in such a way that they can be scarcely separated from one another. The events in the life of Jesus of Nazareth also formed part of the history of Israel, the political and economic history of the Roman Empire, the history of religion, the history of ideas, the history of human culture (broadly understood), of the human species, of planet Earth and of the universe itself. Again it is somewhat imprecise to speak of story here since these events may be told in the form of a story (a his-story or a her-story) but such story-telling will always follow after these events, often much later. The focus here is more on the sequence of events. It is especially important to see that these are multiple layers of one and the same sequence of events.

I suggest that these events may be interpreted, through the eyes of Christian faith, as events in which God has acted in history, not only in and through the history of the Judeo-Christian tradition but indeed in the history of the universe. This, one may suggest, again somewhat imprecisely, may be regarded as God's story, that is, the story of God's work.

- There were numerous early accounts of the story of Jesus of Nazareth, his birth, life, baptism, ministry, passion, death, resurrection and Ascension. These accounts include the earliest oral witnesses, the oral tradition that developed from that, the first and the later written versions of the gospels, but also versions outside the Christian tradition that are no longer available - the story of Jesus as told, for example, from the perspective of the Sanhedrin, the Zealots and the Roman rulers. Here one may speak properly of story, although the dominant story form of such accounts is also interspersed with a variety of other genres. In his The analogical imagination David Tracy offered a proposal as to how such genres may be related to one another. He suggested that the dominant genres were proclamation supported by narrative and that these were balanced by 'corrections' such as apocalyptic and doctrine. In addition, one may identify a wide range of other minor genres in the biblical texts.

In some cases these accounts of the significance of the life and work of Jesus Christ may also be captured in the genre of a cosmological narrative. In my inaugural lecture I offered some observations on the role of such cosmological narratives. I commented on the ways in which they provide answers, in a narrative form to questions about one's origin, place, vocation, struggles and destiny. Following Barth, Frei, Lindbeck and others I also suggested that these stories may create a habitable 'world' in which people, indeed whole cultures and civilizations may live. Thus the story is not so much a part of culture; the story creates a 'world' (an interpretative framework) which a whole culture may

See David Tracy \& Robert Grant, A short History of the interpretation of the Bible (London: SCM Press, 1984), pp. 174-180. 
inhabit. Here it should be noted that only some of the witnesses to Jesus Christ are expressed within this genre. Obvious New Testament examples would include John 1, Romans 8 and Colossians 1. As we will see below, when these different versions of such a cosmological narrative are read together, a more comprehensive 'story' is constructed.

- It is also possible to tell the story of how these quite different stories about Jesus were told. Contemporary New Testament scholarship has helped to reconstruct this story, namely with reference to the coming into being of the corpus of writings later included in the New Testament - starting from the early letters of Paul to the gospel of Mark, the later gospels of Matthew and Luke, the gospel of John, the deutero-Pauline epistles and the Catholic epistles. Old Testament scholars have done similar work on this corpus of writings. These 'stories' came from different periods and were often told by making use of earlier writings and in (critical) response to such earlier stories. Yet another layer is the story of how these writings were collected (long after they were finalised as literary texts) and included (or not included) in what became known as the canonical writings. Here 'the story of the Bible' refers to the coming into being of the biblical texts and not to the events narrated in the biblical texts. To make matters more complex, one may also seek to reconstruct the story of contemporary New Testament scholarship, that is, the arduous way in which this story was reconstructed through the past two centuries of research.

- These 'stories' (more precisely 'writings') were used by their earliest and their later readers within the context of Christian gatherings. Here one may say that the stories about Jesus were retold, reinterpreted and re-enacted in a range of ecclesial activities including witnesses, confessions, prayers, hymns, doxologies, liturgies, preaching, pastoral care, diaconal service, Christian education, moral codes and the emergence of church orders. Here the story of Jesus of Nazareth was told as the story of the crucified and resurrected Christ. These acts of re-appropriations constitute the 'story' of the Christian tradition in its multiple facets. Moreover, this story became embedded in the story of the (work of the) triune God. Again it should be noted that the word 'story' is used here imprecisely. As the list of forms of expression above indicates, not all these ways of 'telling the story' are indeed in the form of a story.

In his contribution on Karl Barth Dirk Smit points out that if one would want to reconstruct how Barth is 'telling the story' of God's work, the place to look would not be only in his dogmatics but primarily in his numerous sermons, for example the sermons which he regularly preached in the local prison.

- These multiple ecclesial ways of 'telling the story' also elicits reflection on 'how' the story is told and how it is best told. This is where theological reflection is born, where the appropriate way(s) of 'telling the story' is problematised. In a footnote to the original version of my inaugural lecture I proposed that one may identify at least four orders of abstraction in such reflection.

First, there is the contemplative wisdom embedded in Christian praxis where (lay) Christians are compelled to reflect on their faith in their everyday lives in order to address a variety of concerns and problems. They would express their insights in conversations with others, in prayer, in proverbs, or in many other modes. When such reflection takes place in a somewhat more structured form in Christian groups it could be described, with Albert Nolan and others, as an exercise in 'doing theology'. It should be noted here that such contemplative wisdom may be expressed in the form of storytelling (or confession) but that it is again rather inaccurate to describe these expressions of wisdom as 'telling the story'. They are better referred to as reflections. 
- A second order of reflection emerges when such reflection is undertaken in a more disciplined and systematic manner, namely in the form of the more formal 'studying' of theology - a wonderful privilege which only some have the opportunity to enjoy. While any confessing Christian can 'do' theology, not everyone engages in 'studying' theology. This is a task that is undertaken in the many sub-disciplines of Christian theology which explore the meaning of the biblical texts against their own backgrounds, the history of Christianity, the confessions of the church, its many ministries and missions and Christian witness in society. It should be noted that such disciplined studying may be able to resolve many theological problems, but that such resolutions do not necessarily surpass the contemplative wisdom of lay Christians. In making this distinction I seek to recognise the priority of Christian faith in relation to reflection on such faith and to deliberately relativise the significance of my own reflections.

I propose that one may see systematic theology as a somewhat more abstract form of theological reflection (compared to Biblical Studies, Church History, Ethics or Practical Theology) that seeks to discern the underlying 'grammar' of Christian witness (the Christian 'story' if you like). It reflects on the content and significance of the Christian faith as this is evident in the biblical roots and the subsequent history of Christianity, its institutions, rituals, myths, ethos and praxis. This underlying grammar cannot be restricted to the exegesis of particular biblical texts, ecclesial manifestations or ecclesial practices. It can only emerge when these are interpreted together. One example would be when the variety of cosmological narratives in the biblical roots of the Christian tradition is read together to construct a somewhat elusive Gestalt that can capture the thrust of these narratives, that can capture the moral of the Christian story.

I have used the term third-order reflection to capture this difference in level of abstraction. One may add that fundamental theology/philosophical theology is then an even more abstract form of reflection that investigates the meaning of concepts such as faith, revelation, witness, religious experience and theology.

It is again important to see that such theological reflections are not typically expressed in the form of a narrative. Reflections are not often 'stories' that are 'told'. They are expressed in a range of other genres such as discursive argumentation, dissertation, dialogues, disputation and so forth. There is no narrative logic necessary here, only a reflective logic and perhaps a hermeneutic logic.

- Theological reflection in the various sub-disciplines of Christian theology elicits, of course, further reflection through teaching and writing theology. This allows one to trace developments in such reflections and to reflect on the history of theological reflection, the history of a discipline and the history of reflection on a particular theological theme. Here one may speak of (systematic) theology as a form of fourthorder reflection, that is, in the form of studying the (third-order) reflections of other theologians and situating the work of another theologian within a history of scholarship. The colloquium assumed that academic theologians typically do engage in a life-time of critical scholarship on a number of selected conversation partners.

It should be noted that such reflection on reflections is typically told in the form of a story, that is, a history. There is an undeniable narrative logic at work here. To make matters even more complex - since there are different versions of such histories one may even write a history of historytelling. One may also position a particular theologian in that story. 
- In my inaugural lecture I suggested that some of these theological themes may themselves be understood in terms of a narrative logic. I am referring here to the seven 'chapters' of God's work that I identified, namely 1) God's acts of creation in the beginning, 2) God's presence in evolutionary history, in the emergence of humanity, and 3 ) in the history of human culture and its distortions (understood in terms of the impact of human sin), 4) God's acts of providence in history, keeping the legacy of sin at bay, 5) God's acts of redemption, 6) the formation of the church, its ministries and missions, and 7) the consummation of all things which is expressed in Christian hope. I described these as 'chapters' in the 'story' of God's labour/God's work and captured this story in terms of the root metaphor of God's economy. ${ }^{2}$

My intention was that this 'story' would be the main focus of the colloquium. I thought I invited colleagues to reflect on how their conversation partners are telling this story. Accordingly, this is the focus of my own contributions on Jürgen Moltmann and Douglas John Hall. Annalet van Schalkwyk also attended to these themes in her review of Van Ruler and McFague respectively, while Anné Verhoef, Susan Rakoczy and Janet Trisk included comments on these themes in the work of Robert Jenson, Elizabeth Johnson and Grace Jantzen respectively.

However, it is quite evident that there is a need for further reflection in this regard. Firstly, theologians are not always 'telling' the story. They more typically offer reflections on the story. Secondly, and more importantly, not all theologians are viewing these as 'a story'. I should admit that the narrative logic is one that was proposed and perhaps imposed by myself in order to resolve a particular problem, namely the way in which the theme of creation has been subsumed under redemption, especially in the history of Protestant theology. Likewise, I suggested, these seven 'chapters' are all too often subsumed under providence, under evolution, under the church, under the social agenda of the church, under God's mission, or under the eschatological consummation. I argued that it is important to do justice to each 'chapter' in an act of 'juggling' and by preserving an underlying narrative logic where the narrative tension between these seven chapters can be maintained. However, I also acknowledged that it is impossible to tell the whole story, that we do not know the story, that it can best be told by Godself, that the story remains incomplete and that, at best, we can gather fragments of the story.

It is indeed not entirely clear that these themes ('chapters') can be related to one another in terms of a narrative logic. The question is this: Can the Christian faith indeed be understood as an attempt to capture the meaning of the story of God's work and is it true that this can only or best be done in the form of a story, that is, by preserving its underlying narrative logic (see section 4 a of my inaugural lecture)?

Some may prefer a hermeneutical logic, or a noetic logic in terms of how we come to know what we think we know. Flip Theron reminded us of Noordmans' view that 'creation' is nothing more than a "spot of light around the cross", because it is only there that we come to know the Creator to be the Father of Jesus Christ. Accordingly, creation is not formation or making and salvation not mending. Instead, creation is understood in terms of a theological judgement (krinein) and therefore separation. It requires spiritual discernment of fragile forms of expression. Clearly, there is no mere narrative logic here where creation can be placed 'in the beginning'.

Christo Lombard referred me recently to AE Loen's work De Vaste Grond (Amsterdam: HJ Paris, s.a.). In an analysis of the historicity of the Word of God Loen employs a somewhat similar analysis of what he calls the great "caesuras" in the history of God's Word, namely creation, sin, reconciliation, redemption and consummation (p. 27, 36-78). Loen finds an underlying unity within this history but locates that in God alone. 
Many contemporary theologians would suggest that, if there is indeed a deeper logic here, that could at best be described as a trinitarian logic - and not so much a narrative logic. This is for example evident from Anné Verhoef's essay on Robert Jenson. In his contribution on Karl Barth, Dirk Smit points out that, for Barth, there is no master narrative, that the grammar of the Christian faith suggests that there is more than narrative. What is at stake here is the self-disclosure of the triune God, the living, acting and speaking God - especially through the 'story' (the event) of Jesus Christ. One may suggest that the (immanent) Trinity is the deepest secret of the story, the deepest mystery embedded in the story, the underlying 'grammar' of the story. This is indicated by especially four features of this 'grammar':

$\sim$ Firstly there is more here than narrative. The person of God cannot be captured fully by God's own story - in the same way that Nelson Mandela's life would always entail more than any (auto-)biographer could do justice to. Several contributors therefore discussed the views of their conversation partners on the person of God and not only on the work of God (see Trisk on Jantzen, Verhoef on Jenson, Rakoczy on Johnson). ${ }^{3}$ Smit maintains that Barth therefore resisted identifying Jesus Christ with history. The person of Jesus Christ is indeed active in history but remains Someone who is behind, above, beyond and more than history (the so-called extra Calvinisticum). The story is indeed the story of Jesus Christ, but Jesus Christ is more than the story.

$\sim$ Secondly, especially in the reformed tradition, it was maintained that the living Word of God cannot be captured in any single formula, a system of dogmatic truths, an underlying rule of faith, a canon within the canon (not even justification through faith), a Scriptural centre, confessions, catechisms, beloved themes or key concepts. This suggests that to identify seven chapters of an underlying narrative of God's work may easily constrain the richness of God's living Word. It may introduce a rigid form of schematisation. Although Scripture should be read as a whole and in terms of its central focus, to capture this centre in any way would tend to replace the actual reading of the biblical texts. What unites the plurality of biblical texts is ultimately only the continued presence and faithfulness of the triune God (Calvin's analogia fidei). Because the unity is not something that we can ever possess, God's word for today has to be re-discovered, ever anew, through the ongoing exposition of the scriptures. Calvin's Institutes was precisely not meant as a dogmatics that could capture the meaning of faith but as a reading aid that would direct people back to read the texts in all their plurality and specificity. Likewise, the reformed confessions do not function as a-historic expressions of the truth but as contextual expressions of how believers heard God's word at a particular point in time. This creative impulse was, of course, soon forgotten in the reformed tradition itself - leading to a rather rigid reformed orthodoxy and later even to fundamentalism.

In my inaugural lecture I deliberately focused on the so-called economic trinity, on what we can say about the triune God on the basis of the work of God. I noted that talk about the immanent trinity is noetically only possible on the basis of the economic trinity, that is, in terms of discerning the presence of the triune God in history. While Barth and others have rightly emphasised the significance of God's self-disclosure in Jesus Christ as crucial for this act of discerning, this becomes in my view only possible on the basis of earlier and later traces of the presence of God's Spirit in the world and therefore in history. In brief, there are many clues to the presence of the Spirit in history but the clearest evidence is found in Jesus Christ. Remarkably, the discussion in the text above on whether there is indeed a story, whether there is an underlying narrative logic here, requires further reflection on the relationship between the economic and the immanent trinity. 
$\sim$ Thirdly, there is the question as to who is telling this story. Are we telling God's story? Or is it better to suggest that God is telling our story? Smit argues that this is the deepest intuition behind Barth's resistance to find some or other master narrative, to ground Christian faith in anything else but in Godself - not even in (the narrative of) God's work. Smit, following Calvin and Barth suggests that this is only possible when we recognise that "this is not our story, but that it is and remains the story of the living God, a story that is told to us, again and again, that we can only be retelling what we have heard and what we are hearing ever anew, that we can never possess this story."

$\sim$ Fourthly, there is the temptation to view a story as merely a story, or one version of the story and to underestimate the truth claims made in Christian confession and proclamation. Danie Veldsman observed, for example, that narrative is 'shy' for the truth, that it 'blushes' when truth claims are made. By contrast, I suggest that the answers to life's ultimate questions provided through cosmological narratives have to be plausible (involving multiple levels of plausibility) if we wish to live by and within such narratives. This should certainly not be understood as a form of constructivism where everyone constructs his or her own (version of the) story, where everyone lives by his or her own version and where such versions remain uncontested in blissful ignorance - as Dirk Smit rightly warns in the concluding paragraph of his essay.

- On the basis of these observations it is possible to come back, to complete a full circle, to the ways in which one's conversation partner is telling this 'story'. For example, how, then, is Jürgen Moltmann relating these theological themes to one another? What is the logic that he employs? How does he understand the relationship between creation and redemption? Or between promissio and missio? Between creation and consummation?

These questions are difficult to address for a number of reasons. Firstly, many authors would resist any such scheme, any particular logic by which these themes are related to one another. They would want to avoid any rigid scholastic schematisation of Christian doctrine. Alternatively, a theologian may acknowledge the need for such a logic, but may then want to allow for more than one form of logic. Secondly, they may not be all that coherent in their own reflections. It may simply be impossible to find such a logic, because there is no such logic. Thirdly, a theologian may have understood the relations between these themes in different ways in her or his career. This is, for example, evident from the work of Karl Barth who captured the whole of Christian faith whenever he explored any one of its themes. Fourthly this logic, even if it was there, may be expressed in different ways in different genres - in a dogmatic work, in preaching and in story telling to one's grandchildren.

Nevertheless, I argue that it remains possible for someone to detect a certain logic (or the lack thereof) in someone else's work. A theologian may not be aware of such a logic until it is highlighted in secondary literature. This is indeed the task of writing dissertations on someone else's theology. Numerous dissertations are indeed of this kind ... "the concept of justification in the thought of ..." or "the relationship between creation and redemption in the book by ...". This indicates, yet again, that it is exceptionally difficult to account for the way(s) in which any major theologian has understood the relationship between all seven theological themes/'chapters' identified above. It would be difficult to that on the basis of one book by a particular author, not to mention a whole oeuvre. Despite such difficulties, I maintain that it is possible to tackle this task, however 
difficult it may be. With Barth, one may even be able to explain this logic in a deceptively simple formula: "Jesus loves me, this I know, for the Bible tells me so!"

It is not only possible to address this task, but also urgent. This urgency follows from my observations above on the multiple ways in which one 'chapter' of the story of God's work has been subsumed under another in twentieth century Christian theologies. It may be true that particular theologians resisted an all too tidy and rigid theological system, logic or order throughout their oeuvre. Others have emphasised the contextual nature of their contributions, suggesting that whatever order there may be should be understood against a highly particular historical background, the challenges of the time and the intended readers. Yet others have humbly recognised the limitations of their own insights and therefore the provisional nature of their reflections, perhaps suggesting the need to refrain from the very attempt to find any form of logic.

In my view, such qualifications, necessary as they may be, may serve as an excuse to evade the crucial theological questions on how we can do justice to protology and eschatology, God's original blessing and (human) suffering, creation and redemption, nature and grace, sin and the forgiveness of sin, church and society. My proposal is that the tensions between these themes can best be maintained through an emphasis on the narrative character of God's work. Despite the limitations and dangers of finding (or constructing) a narrative logic here, the alternative is not the absence of such a logic but the distorted logic that is all too often detected through secondary scholarship in the work of even our most illustrious conversation partners. It would be better to be explicit about the (distorted) logic that one does employ than to pretend not to adopt any form of logic or to jump from one form of logic to another in rapid succession.

This task of reflection through secondary literature, I suggest, may be understood as a form of fourth-order theological reflection. If systematic theology may be seen as third-order reflection, then critical reflection on a particular contribution to systematic theology may require such fourth-order theological reflection. This last form of reflection is found in debates amongst professional theologians and emerges as a result of a recognition of the conflicting diversity of third-order theological positions. In discourse on African Christian theology this form of theological reflection, offering a critique of the work of another African theologian, is not yet well developed.

\section{'are telling'}

It is not necessary to investigate the possible meanings of these words here in any detail. We have seen that in some cases where a narrative logic is inescapable, that theological reflection may well be done in the form of story-telling. In other cases such reflection on 'the story' may be in the form of a critical review, a critical analysis or any other genre for writing theological texts. There are some similarities here between theological reflection and the literary analysis of a narrative (a novel, a myth, a parable or a fable). In yet other cases the object of theological reflection is simply not a story. In such cases the phrase 'telling the story' can be used only metaphorically. Such a metaphor may lead to utter confusion, but it may have attractions of its own, if only because the question posed by the colloquium seems to have been quite catchy.

One further comment may be added on the present tense used here. In the case of living theologians this may be taken to mean: How does a particular theologian understand the story of God's work at the moment? That may invite reflection on the contrast between that and his or her earlier work. However, such a limitation would clearly be too restrictive. The present tense is therefore used here imprecisely. It could also include the work of deceased 
theologians - in the sense that their writings are still available and they are still read by their South African conversation partners.

\section{'how'}

Again it is not necessary to explore the 'how' employed in the question. It was stressed above that this question emerges as a result of challenges that people experience in their life of faith that would then require some degree of disciplined reflection.

The 'how' here at least acknowledges that the story be may told in different ways and that it may be interesting to compare the ways in which 'they' are telling the story.

\section{An open-ended Invitation}

As indicated above, the contributions included in volumes 97 and 98 of Scriptura are derived from the colloquium held in October 2007. However, it should be noted that not all papers read at the colloquium were submitted for publication, that all papers were subjected to the normal process of peer review and that those who could not attend the colloquium were invited to submit an article for publication nevertheless. My own essay on Douglas John Hall was, for example, not discussed at the colloquium but flows from this open invitation.

Given the number of articles, including some rather lengthy ones, not all of these could be published in a single edition of Scriptura and are therefore spread over two volumes (Scriptura 97 and 98). The sequence in terms of the birth dates of the conversation partners will be maintained. Prof Christo Lombaard's contribution on "How Van Ruler tells God's story" will be included in volume 101 of Scriptura in 2009. This volume will focus on Van Ruler's theology as part of the centenary celebration of this esteemed and prolific Dutch theologian.'

As indicated above, the selection of conversation partners whose versions of the story are told here remain quite arbitrary. It is indeed necessary to gather more versions of 'the story'. More specifically it would be attractive to gather a number of other versions, from other contexts. Personally I am especially keen to encourage the development of secondary literature on other African theologians. In this way a richer mosaic of stories may accrue. The publication of this very selective series of contributions on "How are they telling the story?" may therefore be regarded as an open invitation to other scholars and to a generation of younger South African theologians to submit for publication contributions on how their own conversation partners are telling the story. Hopefully this collection of essays can serve as a template on which others may improvise.

When a larger corpus of such contributions is gathered in this way we may also collectively be able to gain further clarity (or confusion!) on which story is being told, on how it is told and whether this is best described as a story. 